\title{
Analyses of Copy Number Variations in Myxopapillary Ependymomas of Cauda Equina
}

\author{
Ali OZEN ${ }^{1}$, Fatih BAYRAKLI' , Ozcan SONMEZ ${ }^{2}$, Irem PEKER EYUBOGLU ${ }^{3}$, Onur ERDOGAN ${ }^{2}$, Can ERZIK ${ }^{3}$, \\ Mustafa Cengiz YAKICIER ${ }^{4}$, Suheyla UYAR BOZKURT ${ }^{5}$

\begin{abstract}
${ }^{1}$ Adiyaman University, Education and Research Hospital, Department of Neurosurgery, Adiyaman, Turkey
${ }^{2}$ Marmara University, Faculty of Medicine and Marmara University, Institute of Neurological Sciences, Departments of Neurosurgery, Istanbul, Turkey

${ }^{3}$ Marmara University, Faculty of Medicine, Department of Medical Biology, Istanbul, Turkey

${ }^{4}$ Acibadem Mehmet Ali Aydinlar University, Faculty of Arts and Sciences, Department of Molecular Biology and Genetics, Istanbul, Turkey
\end{abstract} \\ ${ }^{5}$ Marmara University, Faculty of Medicine, Department of Pathology, Istanbul, Turkey
}

Corresponding author: Fatih BAYRAKLI fbayrakli@gmail.com

\section{ABSTRACT}

AIM: To identify the copy number variations that are specific to myxopapillary ependymomas (MPEs) of the cauda equina.

MATERIAL and METHODS: The patient cohort included five patients who underwent resection of histologically confirmed MPEs. Tumor samples collected during surgery and stored in liquid nitrogen as well as corresponding blood samples collected were analyzed. Genomic DNA from the venous blood and tumor samples was obtained using standard techniques and hybridized to a Cytoscan 750K Array in accordance with the manufacturer's introductions.

RESULTS: As a novel finding, amplification on chromosome 14q32.33 was detected in all tumor and blood samples, except one tumor sample. All tumor tissues also showed amplification on chromosomes 5, 7, 9, and 16.

CONCLUSION: Although further studies with larger cohorts are required to identify genes involved in MPE tumorigenesis and to validate our results, these findings provide a basis for advanced molecular biological and genetic studies of MPEs.

KEYWORDS: Myxopapillary ependymoma, Copy number variation, Cauda equina, Molecular biology, Chromosomal aberration

ABBREVIATIONS: MPE: Myxopapillary ependymoma, MR: Magnetic resonance

\section{INTRODUCTION}

$\mathrm{E}$ pendymomas are primary tumors of the central nervous system that originate from the walls of the cerebral ventricles and the spinal cord canal. Although the histological features are similar, ependymomas exhibit highly variable clinical behaviors possibly due to genetic heterogeneity; therefore, these tumors are divided into five different subtypes (5).

A myxopapillary ependymoma (MPE), with distinct histological features, arises in specific regions of the spine, including the conus medullaris, cauda equina, or filum terminale (4). Although classified as a grade I tumor, an MPE is associated with distant metastases, subarachnoid dissemination, and late recurrences, particularly in the pediatric population (16).

A copy number variation, which is a cell-owned genomic structural number variation, is one of the causes of genetic diversity as well as tumorigenesis. Copy number variations results in an abnormal gene copy number in the cell via amplification and deletion events. Such changes cause several alterations in genomic segment numbers in tumor cells, which is an important structural change that plays an important role in tumorigenesis (13).
Ali OZEN (1): 0000-0002-3035-0648

Fatih BAYRAKLI (D) : 0000-0003-0668-5453

Ozcan SONMEZ :D : 0000-0002-2023-3456
Irem PEKER EYUBOGLU (1) : 0000-0003-0764-9841

Onur ERDOGAN

Can ERZIK
Mustafa Cengiz YAKICIER (1) : 0000-0003-3640-9417 Suheyla UYAR BOZKURT (D) : 0000-0002-5947-947X 
To identify viable drug targets and predict biological behaviors, elucidating the molecular mechanisms underlying the development of ependymomas is crucial. Therefore, for the first time, to the best of our knowledge, we aimed to assess copy number variations in five histologically confirmed cases of MPE by analyzing blood and tumor samples.

\section{MATERIAL and METHODS}

The study protocol was approved by the Clinical Research Ethics Committee of Marmara University Faculty (approval no. 09.2016.147) and was conducted in accordance with the tenets of the Declaration of Helsinki.

\section{Patient Selection}

The study cohort included five patients who underwent surgeries for pathologically confirmed MPEs of the cauda equina. Informed consent was obtained from all patients prior to study inclusion. Tumor samples were collected at the time of surgery and stored in liquid nitrogen. In addition, blood samples were collected.

\section{Single Nucleotide Polymorphism Genotyping and Copy Number Variation Analyses}

Genomic DNA from the peripheral venous blood and tumor tissue samples was obtained using standard techniques and hybridized to a Cytoscan 750K Array (Affymetrix, Inc., Santa Clara, CA, USA), in accordance with the manufacturer's instructions. Median centering of copy number probes was performed before summarization and visualization using the GeneChip ${ }^{\circledR}$ Scanner $30007 \mathrm{G}$ System (Affymetrix, Inc.). Significant focal regions of amplification or deletion were identified using the Chromosome Analysis Suite 3.1 software package (Affymetrix, Inc.)

\section{RESULTS}

\section{Patient Demographics}

Of the five patients (age, 30-45 years) included for analysis, four were male and one was female. Radiological and histological findings were similar among all patients. Representative preoperative T1- and T2-weighted magnetic resonance (MR) images are shown in Figure 1A, B, whereas representative histopathological images of patient 3 are shown in Figure 2AC.

\section{Copy Number Variations}

Screening of all blood and tumor samples revealed numerous amplifications and a few deletions. A representative karyotype is shown in Figure 3. Whole genome analysis of the blood sample of patient 1 demonstrated amplifications on chromosomes 7q36.2 and 14q.32.33, whereas that of the tumor sample revealed amplifications on chromosomes 5, 7, 9, 16, 18 , and 20 and partial amplifications on chromosomes 8p23.3 and $14 q 32.33$. Whole genome analysis of the blood sample of patient 2 showed amplifications on chromosome 14q32.33, whereas that of the tumor sample exhibited amplifications on chromosomes 5, 7, 9, 16, and 17. The blood sample of patient 3 demonstrated amplification on chromosome 14q32.33 and deletion on chromosome 16p13.3, whereas the tumor sample contained whole amplifications on chromosomes 5, 7, 9, 16, 18, and $21 q$ and partial amplifications on chromosomes 6p25.3, 14q32.33, and Yp11.2. The blood sample of patient 4, who exhibited the most aggressive tumor in the present study, showed amplifications on chromosomes 14q32.33, 20p12.1, 22q11.22, and Yp11.2 and deletions on chromosomes 1q21.1 and 16p13.11. Besides having the most aggressive tumor, patient 4 also exhibited the greatest number of copy number variations. The tumor sample of patient 4 showed whole amplifications on chromosomes 5, 7, 9, 16, 18, and 20, partial amplification on chromosome 14q32.33, and deletion on chromosome 1q21.1. The blood sample of patient 5 exhibited partial amplifications on chromosomes 1q31.1 and 14q32.33, whereas the tumor sample showed partial amplifications on chromosomes 1q31.1, 14q32.33, and Yp11.2. Chromosomal gains and losses are shown in Table $\mathrm{I}$.

All tumor samples exhibited a higher number of chromosomal variations compared with that of the blood samples; this finding was compatible with the genetic structure of tumors. Notably, the blood and tumor samples of all patients, except the tumor sample of patient 2, showed amplification on chromosome 14q32.33. All tumor samples showed amplifications on chromosomes 5, 7, 9, and 16. Chromosome 20 of four tumor samples and chromosome 18 of three
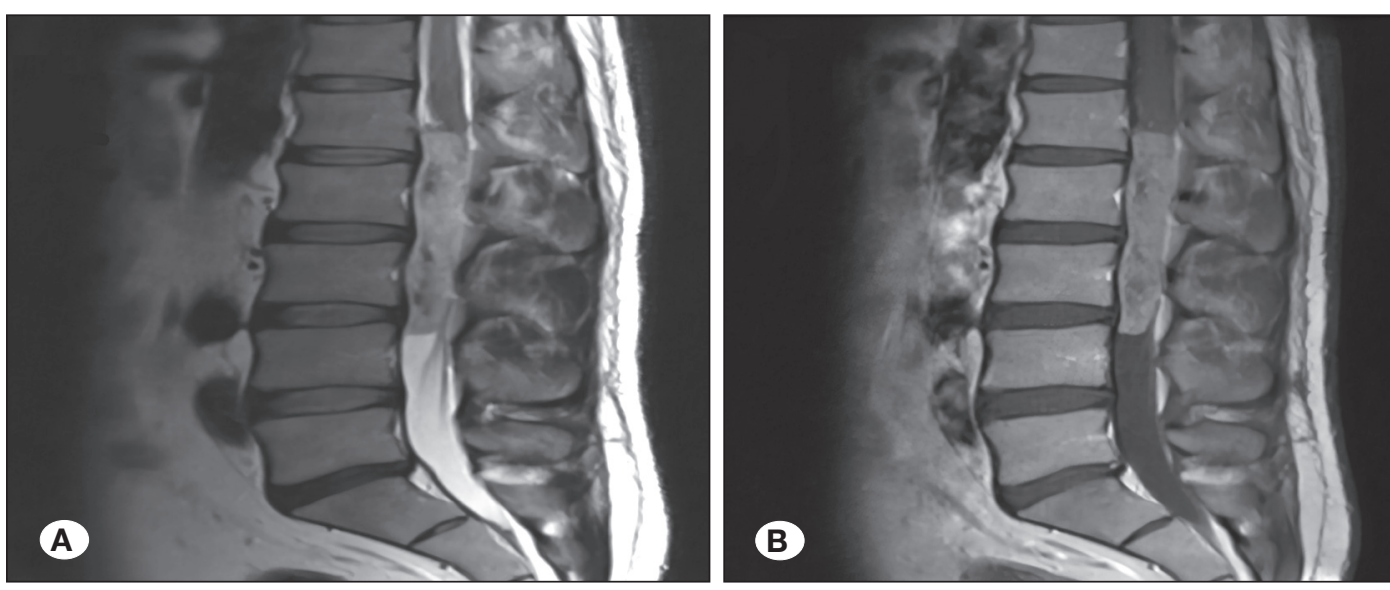

Figure 1: Representative MR images of "patient 3". A preoperative T2-weighted MR image showing high intensity areas (A). A preoperative T1-weighted MR image with contrast showing homogenous enhancement patterns (B). 
Ozen A. et al: Myxopapillary Ependymomas

Table I: Chromosomal Aberration of Cases

\begin{tabular}{|c|c|c|}
\hline Patient & Blood & Tumor \\
\hline I & $\begin{array}{c}\text { 7q36.2 (amp) } \\
\text { 14q32.33 (amp) }\end{array}$ & $\begin{array}{c}5,7,9,16,18,20(\mathrm{amp}) \\
8 \mathrm{p} 23.3(\mathrm{amp}) \\
14 \mathrm{q} 32.33(\mathrm{amp})\end{array}$ \\
\hline II & 14q32.33 (amp) & $5,7,9,16,17$ (amp) \\
\hline III & $\begin{array}{c}\text { 14q32.33 (amp) } \\
\text { 16p13.3 (del) }\end{array}$ & $\begin{array}{c}5,7,9,16,18,20,21 q(\mathrm{amp}) \\
6 \mathrm{p} 25.3(\mathrm{amp}) \\
14 q 32.33(\mathrm{amp}) \\
\text { Yp11.2 (amp) }\end{array}$ \\
\hline IV & $\begin{array}{c}\text { 1q21.1 (del) } \\
\text { 6p13.11 (del) } \\
\text { 14q32.33 (amp) } \\
\text { 20p12.1 (amp) } \\
\text { 22q11.22 (amp) } \\
\text { Yp11.2 (amp) }\end{array}$ & $\begin{array}{c}5,7,9,16,18,20 \text { (amp) } \\
\text { 1q21.1 (del) } \\
14 q 32.33(\mathrm{amp})\end{array}$ \\
\hline $\mathbf{v}$ & $\begin{array}{c}1 \mathrm{q} 31.1 \text { (amp) } \\
14 \mathrm{q} 32.33 \text { (amp) }\end{array}$ & $\begin{array}{c}\text { 5,7,9,16,20 (amp) } \\
\text { 1q31.1(amp) } \\
\text { 14q32.33(amp) } \\
\text { Yp11.2(amp) }\end{array}$ \\
\hline
\end{tabular}

Del: Deletion, Amp: Amplification. tumor samples contained amplifications. Patient 4, who was diagnosed with the recurrence of an aggressive tumor, had undergone three surgeries because of metastasis - two surgeries of the thoracic spine and one of the posterior fossa. All metastases were histologically confirmed as MPEs. Whole genome analysis of the blood sample of patient 4 revealed unique genetic alterations to chromosomes 22q11.2 and 20p11.2, whereas the tumor sample exhibited deletion on chromosome 1q21.1. The tumor samples of patients 3 and 5 and blood sample of patient 4 exhibited amplifications on chromosome Yp11.2.

\section{DISCUSSION}

It has long been known that chromosomal abnormalities are present in tumor cells. Unlike normal cells, tumor cells are typically aneuploid and often contain translocations, deletions, and/or amplifications (14). Previous studies have revealed location-specific molecular profiles and high intratumoral heterogeneity at each location of the central nervous system $(15,17)$. To elucidate the biological basis of regional heterogeneity of ependymomas, most studies have focused on field-specific molecular changes by analyzing genomic sequences $(8,11)$. To understand intra-tumoral heterogeneity in all anatomical compartments (supratentorial, infratentorial,
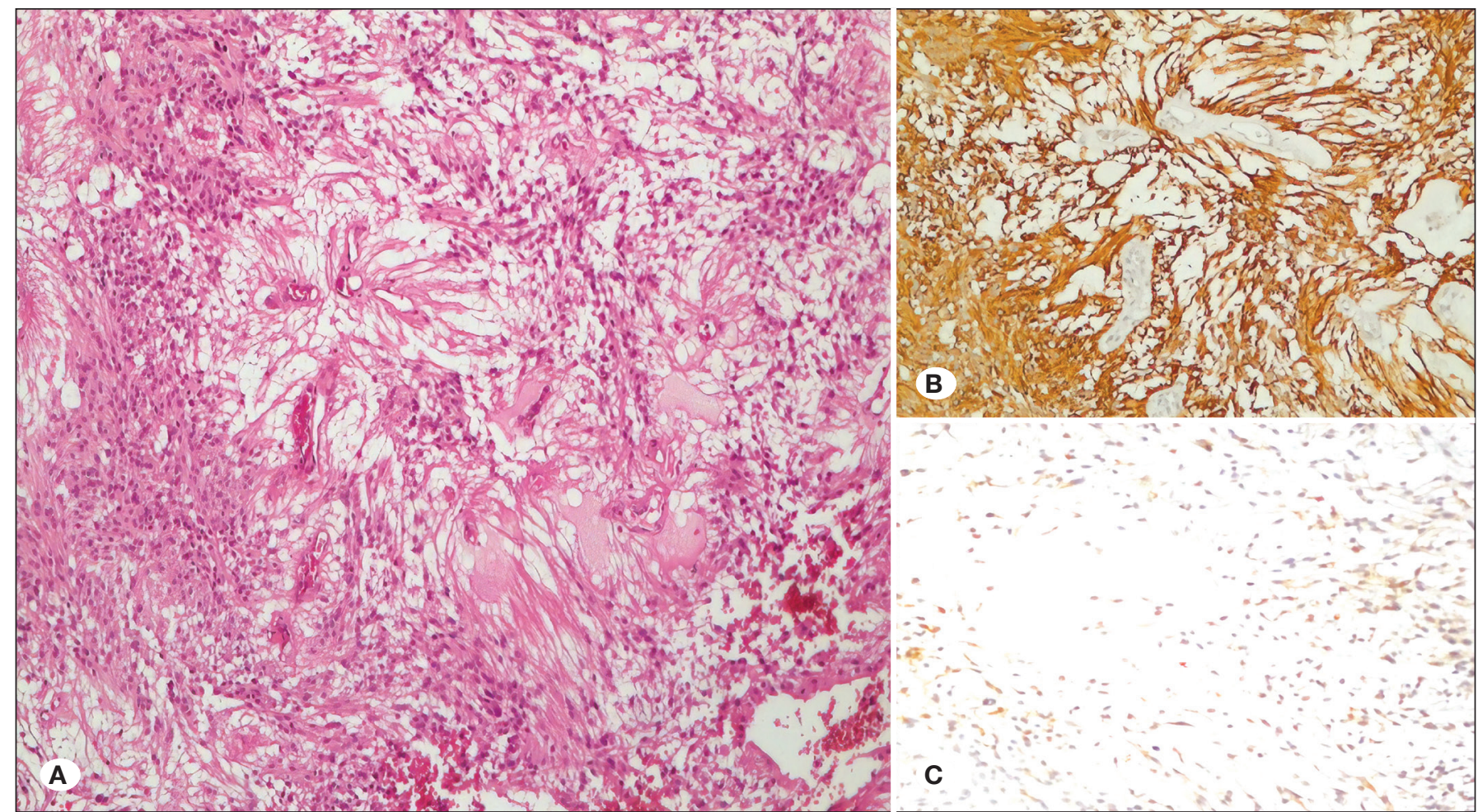

Figure 2: Histopathological findings of "patient 3". Microscopic analysis revealed elongated tumor cells surrounded by vascularized myxoid stromal cores (A). Myxoid matrix accumulation between vessels and perivascular tumor cells. Tumor cells had round nuclei and delicate chromatin. Papillary structures were not apparent. There was no mitosis or necrosis. Myxoid areas were stained with Alcian blue. The tumor cells showed diffuse staining for vimentin and glial fibrillary acidic protein (GFAP) (B) and dot-like staining for epithelial membrane antigen (EMA) (C). These findings confirmed the diagnosis of an MPE. A) Perivascular arrangement of elongated tumor cells surrounding vascularized myxoid cores (H\&E stain, $\times 100$ ). B) Diffuse GFAP immunoreactivity in tumor cells (GFAP stain, $\times 200)$. C) Dotlike EMA immunoreactivity in tumor cells (EMA stain, $\times 200$ ). 


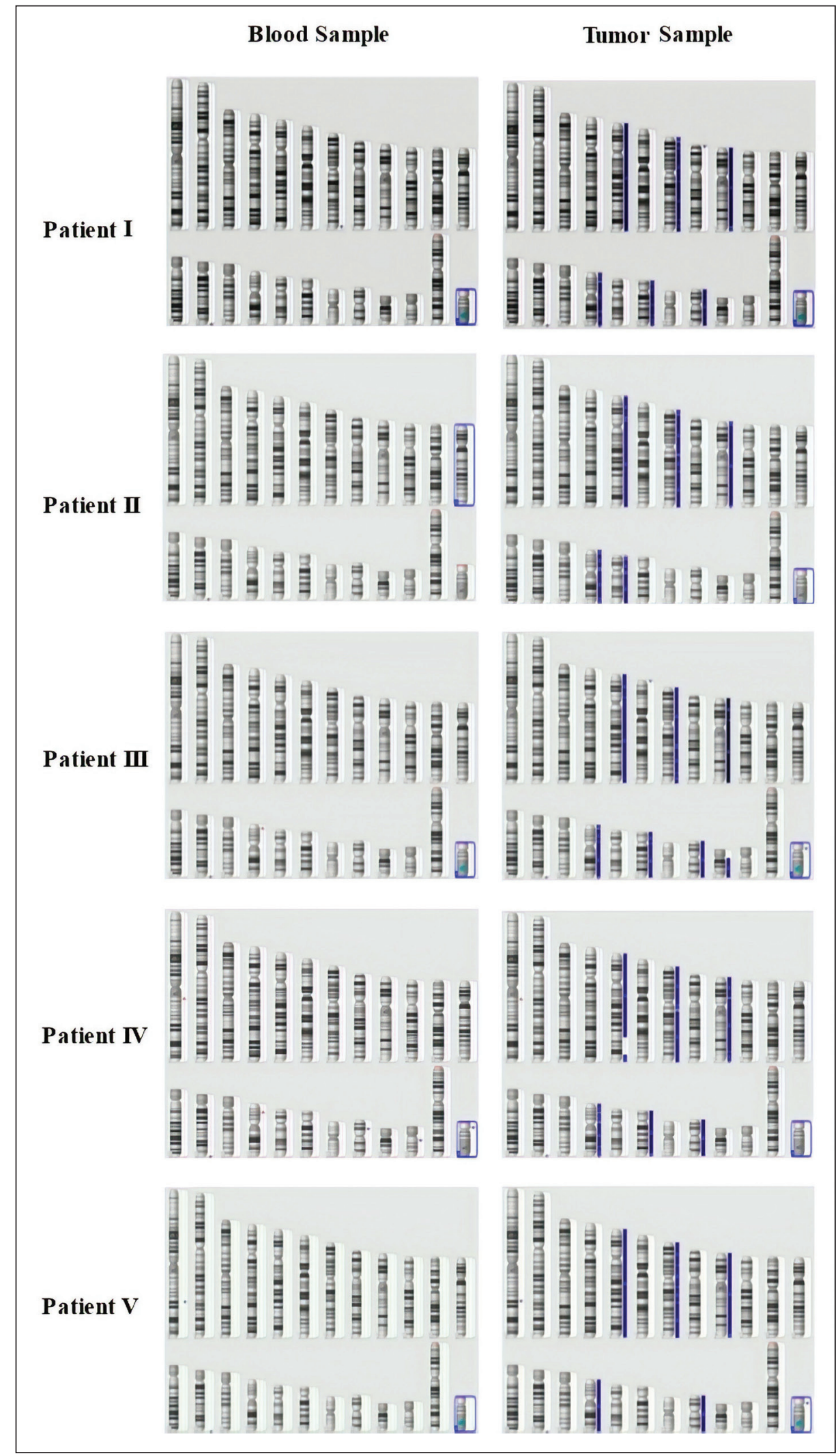

Figure 3: Karyotype view of copy number variation analyses of the blood and tumor samples from all patients. Blue lines indicate amplification, and red lines indicate deletion. 
and spinal), researchers have employed whole genome and whole exon sequencing of both supratentorial (10), and posterior fossa $(6,17)$ ependymomas.

In the present study, MPEs of five patients were screened using microarray-based comparative genomic hybridization. As previously reported in the literature, numerous chromosomal aberrations have been identified in ependymomas (3). The present study is the first to demonstrate chromosomal aberrations throughout the entire genome of MPEs located in the cauda equina.

In a study of supratentorial ependymomas, Parker et al. discovered that genomic assemblages clustered in an extremely focal region on the chromosome 11q12.1-q13.3 (10). Chromosomal fragments in this region contained fusions of the uncharacterized C11orf95-RELA fusion protein, which is the primary effector of the nuclear factor-kB pathway. These fusions occurred in approximately $70 \%$ of the supratentorial tumors and were strictly specific to this region. Moreover, that study identified YAP1-MAMLD1 fusion in supratentorial ependymomas without RELA fusion. Both C11orf95-RELA and YAP1-MAMLD1 fusions were identified using DNA methylation studies, which showed that the supratentorial ependymomas containing the YAP1 fusion were characterized by a subgroup without RELA fusion (9). Unlike the C11orf95-RELA fusion, no chromothripsis was detected in YAP1 fusions. Both fusion proteins were oncogenic. Malgulwar et al. reported that the clinicopathological features of supratentorial ependymomas included C11orf95-RELA and YAP1 gene fusions (7). In the present study, there was no genomic similarity between supratentorial ependymomas and MPEs.

Compared with the studies on intracranial and spinal ependymomas, those on the molecular biology of MPEs are limited. Lee at al. found that MPEs tended to have a high incidence of NEFL mutations (3); however, no unique genetic mutations were observed. A study on the variations of spinal ependymomas conducted by Johnson et al. detected gains of chromosomes 4, 7, 9, 12, 15q, and $18 q$ and deletion on chromosome $22 q(2)$. The results of the present study revealed gains of chromosomes 7 and 9 , without any other variations, which could be attributed to the lack of genetic information of MPEs as these tumors differ from other spinal ependymomas. Santi et al. investigated the number of chromosome 7 transcripts in a total of 27 adult ependymomas, of which 13 were MPEs, using chromogenic in situ hybridization (12). Chromosome 7 polysomy was observed in all 13 MPEs but not in other ependymomas. Similarly, the results of the present study showed that all tumor tissues exhibited a chromosome 7 polysomy. Barton et al. employed a microarray for the gene expression analysis of 5 cases of pediatric MPEs and 23 cases of pediatric intracranial ependymomas (1). The gene expression microarray data revealed differences in the gene expression profiles of MPEs and pediatric intracranial ependymomas. Overexpression of HOXB13 was determined to be specific to MPEs. The overexpression of HOX genes in MPEs and oncogenic functions of the HOX gene family suggest that this gene family is a potential target for the treatment of MPEs. HOXB13 is located at chromosome 17q21. In the present study, a tumor sample from only one patient revealed a gain of chromosome 17 .

In contrast to prior reports, the results of the present study demonstrated that amplification on the chromosome 14q32.33 region in tumor tissues and matched blood samples of our patients is a novel copy number variation.

\section{CONCLUSION}

A microarray platform was employed in the present study to detect high-resolution copy number variations across the whole genome, which identified novel chromosomal aberrations in MPEs. Molecular biological and genetic studies of MPEs are rare in the literature. This is the first study to report copy number variations throughout the entire MPE genome. Previous studies of MPEs have typically focused on gene expression profiles. In the present study, chromosomes $5,7,9$, and 16 were amplified in all patients, particularly the tumor tissues. Furthermore, amplification on the chromosome 14q32.33 region in blood and tumor tissue samples from our patients revealed a novel copy number variation. Genetic analysis of chromosome 14q32.33 identified >200 genes. However, further studies with larger cohorts are required to identify genes involved in MPE tumorigenesis as well as to validate our results. Nonetheless, these findings provide a basis for advanced molecular biological and genetic studies of MPEs.

\section{REFERENCES}

1. Barton VN, Donson AM, Kleinschmidt-Demasters BK, Birks DK, Handler MH, Foreman NK: Unique molecular characteristics of pediatric myxopapillary ependymoma. Brain Pathol 20:560-570, 2010

2. Johnson RA, Wright KD, Poppleton H, Mohankumar KM, Finkelstein D, Pounds SB, Rand V, Leary SES, White E, Eden C, Hogg T, Northcott P, MacK S, Neale G, Wang YD, Coyle B, Atkinson J, Dewire M, Kranenburg TA, Gillespie Y, Allen JC, Merchant T, Boop FA, Sanford RA, Gajjar A, Ellison DW, Taylor MD, Grundy RG, Gilbertson RJ: Cross-species genomics matches driver mutations and cell compartments to model ependymoma. Nature 466:632-636, 2010

3. Lee $\mathrm{CH}$, Chung $\mathrm{CK}$, Kim CH: Genetic differences on intracranial versus spinal cord ependymal tumors: A metaanalysis of genetic researches. Eur Spine J 25:3942-3951, 2016

4. Leeper H, Felicella MM, Walbert T: Recent advances in the classification and treatment of ependymomas. Curr Treat Options Oncol 18(9):55, 2017

5. Louis DN, Perry A, Reifenberger G, Deimling A, FigarellaBranger D, Cavenee WK, Ongaki H, Wiestler OD, Kleihues P, Ellison DW: The 2016 World Health Organization classification of tumors of the central nervous system: A summary. Acta Neuropathol 131:803-820, 2016

6. Mack SC, Witt H, Piro RM, Gu L, Zuyderduyn S, Stütz AM, Wang X, Gallo M, Garzia L, Zayne K, Zhang X, Ramaswamy V, Jäger N, Jones DTW, Sill M, Pugh TJ, Ryzhova M, Wani KM, Shih DJH, Head R, Remke M, Bailey SD, Zichner T, Faria CC, Barszczyk M, Stark S, Seker-Cin H, Hutter S, Johann P, 
Bender S, Hovestadt V, Tzaridis T, Dubuc AM, Northcott PA, Peacock J, Bertrand KC, Agnihotri S, Cavalli FMG, Clarke I, Nethery-Brokx K, Creasy CL, Verma SK, Koster J, Wu X, Yao Y, Milde T, Sin-Chan P, Zuccaro J, Lau L, Pereira S, CasteloBranco P, Hirst M, Marra MA, Roberts SS, Fults D, Massimi L, Cho YJ, Meter T, Grajkowska W, Lach B, Kulozik AE, Deimling A, Witt O, Scherer SW, Fan X, Muraszko KM, Kool M, Pomeroy SL, Gupta N, Phillips J, Huang A, Tabori U, Hawkins C, Malkin D, Kongkham PN, Weiss WA, Jabado N, Rutka JT, Bouffet E, Korbel JO, Lupien M, Aldape KD, Bader GD, Eils R, Lichter P, Dirks PB, Pfister SM, Korshunov A,Taylor MD: Epigenomic alterations define lethal CIMP-positive ependymomas of infancy. Nature 506:445-450, 2014

7. Malgulwar PB, Nambirajan A, Pathak P, Faruq M, Rajeshwari M, Singh M, Suri V, Sarkar C, Sharma MC: C11orf95-RELA fusions and upregulated NF-KB signalling characterise a subset of aggressive supratentorial ependymomas that express L1CAM and nestin. J Neurooncol 138:29-39, 2018

8. Modena P, Lualdi E, Facchinetti F, Veltman J, Reid JF, Minardi S, Janssen I, Giangaspero F, Forni M, Finocchiaro G, Genitori L, Giordano F, Riccardi R, Schoenmakers EFPM, Massimino M, Sozzi G: Identification of tumor-specific molecular signatures in intracranial ependymoma and association with clinical characteristics. J Clin Oncol 24:5223-5233, 2006

9. Pajtler KW, Witt H, Sill M, Jones DTW, Hovestadt V, Kratochwil F, Wani K, Tatevossian R, Punchihewa C, Johann P, Reimand J, Warnatz HJ, Ryzhova M, Mack S, Ramaswamy V, Capper D, Schweizer L, Sieber L, Wittmann A, Huang Z, Sluis P, Volckmann R, Koster J, Versteeg R, Fults D, Toledano $\mathrm{H}$, Avigad S, Hoffman LM, Donson AM, Foreman N, Hewer E, Zitterbart K, Gilbert M, Armstrong TS, Gupta N, Allen $\mathrm{JC}$, Karajannis MA, Zagzag D, Hasselblatt M, Kulozik AE, Witt O, Collins VP, Hoff K, Rutkowski S, Pietsch T, Bader G, Yaspo ML, Deimling A, Lichter P, Taylor MD, Gilbertson R, Ellison DW, Aldape K, Korshunov A, Kool M, Pfister SM: molecular classification of ependymal tumors across All CNS compartments, histopathological grades, and age groups. Cancer Cell 27:728-743, 2015

10. Parker M, Mohankumar KK, Punchihewa C, Weinlich R, Dalton JD, Li Y, Lee R, Tatevossian RG, Phoenix TN, Thiruvenkatam R, White E, Tang B, Orisme W, Gupta K, Rusch M, Chen X, Li Y, Nagahawhatte P, Hedlund E, Finkelstein D, Wu G, Shurtleff S, Easton J, Boggs K, Yergeau D, Vadodaria B, Mulder HL, Becksford J, Gupta P, Huether R, Ma J, Song G, Gajjar G, Merchant T, Boop F, Smith A, Ding L, Lu C, Ochoa K, Zhao D, Fulton RS, Fulton LL, Mardis ER, Wilson RK, Downing JR, Green DR, Zhang J, Ellison DW, Gilbertson RJ: C11 orf95-RELA fusions drive oncogenic NF-kB signalling in ependymoma. Nature 506: 451-455, 2014
11. Raghunathan A, Wani K, Armstrong TS, Vera-Bolanos E, Fouladi M, Gilbertson R, Gajjar A, Goldman S, Lehman NL, Metellus P, Mikkelsen T, Necesito-Reyes MJT, Omuro A, Packer RJ, Partap S, Pollack IF, Prados MD, Robins HI, Soffietti R, Wu J, Miller CR, Gilbert MR, Aldape KD: Histological predictors of outcome in ependymoma are dependent on anatomic site within the central nervous system. Brain Pathol 23:584-594, 2013

12. Santi M, Quezado M, Ronchetti R, Rushing EJ: Analysis of chromosome 7 in adult and pediatric ependymomas using chromogenic in situ hybridization. J Neurooncol 72:2528,2005

13. Stratton MR, Campbell PJ, Futreal PA: The cancer genome. Nature 458:719-724, 2009

14. Thompson SL, Compton DA: Chromosomes and cancer cells. Chromosom Res 19:433-444, 2011

15. Wani K, Armstrong TS, Vera-Bolanos E, Raghunathan A, Ellison D, Gilbertson R, Vaillant B, Goldman S, Packer RJ, Fouladi M, Pollack I, Mikkelsen T, Prados M, Omuro A, Soffietti R, Ledoux A, Wilson C, Long L, Gilbert MR, Aldape $\mathrm{K}$ : A prognostic gene expression signature in infratentorial ependymoma. Acta Neuropathol 123:727-738, 2012

16. Weber DC, Wang $Y$, Miller R, Villà $S$, Zaucha R, Pica $A$, Poortmans P, Anacak Y, Ozygit G, Baumert B, Haller G, Preusser M, Li J: Long-term outcome of patients with spinal myxopapillary ependymoma: Treatment results from the MD Anderson Cancer Center and institutions from the Rare Cancer Network. Neuro Oncol 17:588-595, 2014

17. Witt $H$, Mack SC, Ryzhova M, Bender S, Sill M, Isserlin R, Benner A, Hielscher T, Milde T, Remke M, Jones DTW, Northcott PA, Garzia L, Bertrand KC, Wittmann A, Yao Y, Roberts SS, Massimi L, Meter TV, Weiss WA, Gupta N, Grajkowska W, Lach B, Cho YJ, Deimling A, Kulozik AE, Witt O, Bader GD, Hawkins CE, Tabori U, Guha A, Rutka JT, Lichter P, Korshunov A, Taylor MD, Pfister SM: Delineation of two clinically and molecularly distinct subgroups of posterior fossa ependymoma. Cancer Cell 20:143-157, 2011 